\section{The fragile contract}

\section{Endless Frontier: Vannevar Bush,} Engineer of the American Century

by G. Pascal Zachary

Free Press: 1997. Pp. 518. \$32.50

\section{Harvey Brooks}

During the Second World War, Vannevar Bush, working with several like-minded colleagues, presided over a historic expansion of the role of organized innovation in society through the wartime Office of Scientific Research and Development (OSRD), which he helped to establish in 1940. The office was set up directly under the patronage of President Franklin Roosevelt, who gave it the authority and resources to initiate development of military technology without the prior approval or formal requirements of the military services.

Near the end of the war, Bush attempted to capitalize on his wartime experience by designing a postwar national science system, as outlined in his famous 1945 report "Science - The Endless Frontier", a classic document in science policy. Ironically, the organizational recommendations of the report, and even the content of the programme it advocated, were largely superseded as a result of other events. Yet the report did present a list of general principles to guide the relationship between the science and engineering community on the one hand and political and other social organizations on the other, principles which considered the two groups as equal partners rather than as servant and master. These principles have proved remarkably durable, helping to propel the United States to a position of scientific, technological, economic and military pre-eminence - a role model to which most of the world now aspires. They haveleft a legacy that many feel is destined to expand into more and more aspects of human life, although not without much opposition and questioning by those who perceive a conflict of these principles with the ideals of a true democratic society.

One indicator of this revolution is that, in every economically developed country, total national expenditures on research and development, both private and public, have grown from a fraction of a per cent of gross national product to nearly three per cent, while total national investment in innovation, defined more broadly to include production and marketing, although not well estimated, probably exceeds 10 per cent. Indeed, this statistic has come to be one of the common economic indicators that define the level of a country's economic and social development.

G. Pascal Zachary has written the first definitive and scholarly biography of Bush (1890-1974). It is based on a thorough review ofBush's newly accessible papers, informed by personal interviews with 54 of his contempo-

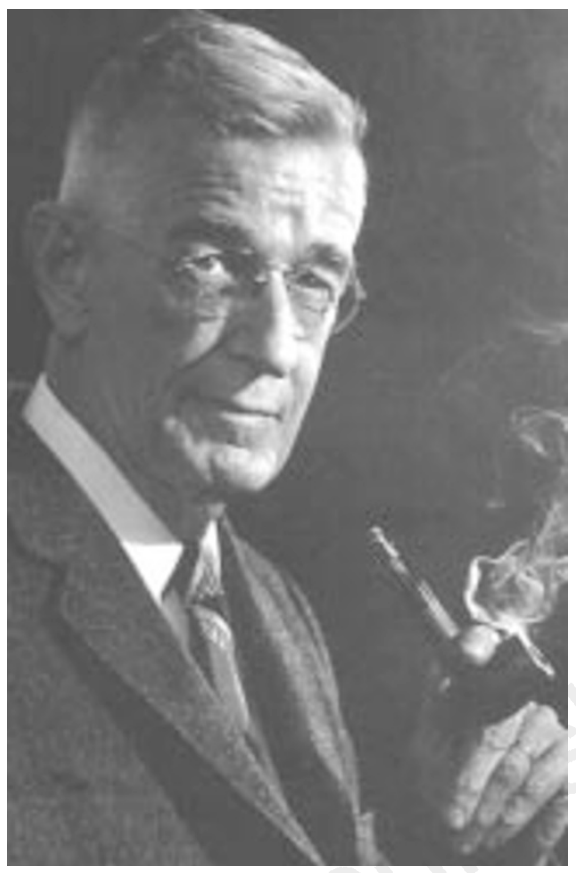

Bush: complex personality full of contradictions and inconsistencies.

raries. The work is extraordinarily well documented, with 73 pages of notes and a sevenpage list of books and other sources.

The picture that emerges is of a complex personality with not a few contradictions and inconsistencies. Bush grew up and was socialized as an engineer in the classic mode of the late nineteenth and early twentieth centuries - that of the lone inventor and resourceful gadgeteer. It was a style that he never fully abandoned, and in which he often sought refuge from the frustrating world of bureaucratic politics, even while in the midst of creating a revolution both in the character of technological innovation as a product of large organizational teamwork, and in the role of experts in society. As a young professor at the Massachusetts Institute of Technology, Bush was an early pioneer in the design of analog computers. He thought about and published much on the potential of the computer and its capacity for amplifying the human intellect — a vision that was the acknowledged source of inspiration for many other early computer designers and entrepreneurs. Yet he was never comfortable with the digital age that eventually emerged and so was never part of the mainstream of computer development.

Bush was temperamentally a political conservative with an inherent distrust of government and politics and of large bureaucracies, both private and public. Yet at the same time he was a shrewd political operator who conceived of, and presided over, one of the largest and most successful networks of bureaucracies that the United States had ever seen. A compulsive solitary inventor who loved to potter in his own home laboratory and machine shop, he nevertheless realized and demonstrated the power of team research. An advocate of competition, he energetically worked at eliminating 'wasteful' competition among the military services.

Initially sceptical of the possibility of an atomic bomb, he became a late convert on the advice of people he trusted and he pushed for the creation of the Manhattan Project outside his own domain of the OSRD. In the face of deep political scepticism, he was one of the first leaders to argue for internationalization of nuclear energy to head off an atomic arms race after the Second World War. He even favoured sharing the 'secret' with Stalin in the hope of averting such a race before it could start, accurately predicting how soon the Russians would test their own bomb.

Unlike the situation with the atomic bomb, Bush resisted through most of the Cold War any all-out effort for the development of an intercontinental ballistic missile or for manned space flight. Zachary points out this inconsistency, attributing it principally, but not entirely, to Bush's reversion to fiscal budgetary conservatism after the return to a more normal economy in the 1940s and to his growing scepticism about the inflated technological ambitions of the military that grew out of its wartime successes.

Zachary provides a good account of the origins of "Science - The Endless Frontier" and the vagaries surrounding its political reception in President Harry Truman's administration after Roosevelt's death. The report equated national welfare and military security with research strength, and outlined a system of permanent federal funding for research, mainly through contracts and grants, and mainly in universities and independent research institutes outside government. He also covers well the subsequent debates about the creation of the National Science Foundation, arguing that the sharp apparent differences among Bush, Harley Kilgore, John Steelman and Truman were much smaller and less consequential in practice for the future than the participants believed at the time, and probably did not justify the five-year delay in the eventual establishment of the foundation, an assessment with which I tend to agree.

A recurrent theme that runs through the biography and which was never resolved either by Bush, or, in my opinion, by the author, is the proper role of expertise and experts in a democracy. In the years just before the Second World War, Bush, along with many of his closest colleagues in a few élite universities and east-coast business communities, as they watched the German military build-up and later the Nazi war machine rolling over Europe, became concerned that dictatorships could run circles around democracies. After the war, he moderated this view, concluding that "all other things being equal, a democracy can outclass any despotism in bringing to bear on the struggle the combined efforts of science, industry and 
military might". Yet he was convinced that it was only because of the war that democracy had performed so well. Remove the prod of war and the US government would revert to past form, as shown by the Truman administration's "exceedinglyloose" handling of arms control in late 1945.

Bush continued to have a profound distrust of 'politics as usual' and aspired to achieving a nonpartisan expertise that could transcend politics and produce the right answer through realistic observation of the facts and analysis untainted by wishful thinking and political preconceptions. This aspiration was closely approximated in his experience with the OSRD. There, shielded from public view by military secrecy, and with unlimited access to Roosevelt, he could acquire the resources and authority needed to fulfil his vision of an independent civilian research-and-development organization that would serve as an equal partner with the military and the industrial leadership of the country, but which would be free to initiate developments without military blessing.

According to Zachary, Bush first conceived of this wartime organization in January 1940 — a remarkably bold vision. "Few civilians short of the president had ever imagined so grand a role in military affairs," says Zachary.

According to Zachary, "Bush himself later confessed that the creation of NDRC [National Defense Research Committee] was 'an end run, a grab by which a small company of scientists and engineers, acting outside established channels, got hold of the authority and money for the program of developing new weapons'. Such a power grab was necessary to launch a 'broad program... on an adequate scale', Bush insisted, but he conceded that it stoked resentment against him." Bush attempted similar tactics in getting Roosevelt to commission "Science - The Endless Frontier", but the strategy did not work out in the more open, participatory environment in which it was released after the end of the war.

Nevertheless, in Bush's mind there remained an inherent tension between the increasingly complicated and technical problems facing government, even in peacetime, and the country's democratic traditions. Bush's solution was a body of civilian technocrats, nonpartisan experts of the highest calibre, free of operational responsibilities for departments or agencies, with delegations of authority to make decisions in the name of the president. In Bush's view their effectiveness would have to depend as much on their detachment from politics as on their specialized knowledge.

This is in a sense the uneasy compromise at which the United States has arrived in practice today with the enormous growth of the staff of the Executive Office and a matching growth of congressional staff and support agencies. But, as Zachary remarks, "the specialization of expertise [has] advanced knowledge but also expanded the possibilities for legitimate disputes about its import" with ample room for the intrusion of politics, especially in the overlapping domains between areas of expertise. We are still struggling for a solution today. This book does not provide one, but it does provide a wealth of new and valuable raw material for the continuation of the debate on expertise and democracy.

Harvey Brooks is emeritus professor at the John F.

Kennedy School of Government, Harvard

University, 79 JFK Street, Cambridge,

Massachusetts 02138, USA.

\section{A bluffer's guide}

\section{Loose Ends}

by Sydney Brenner

Current Biology: 1997. Pp. 128. £12.50, \$20

\section{Walter Gratzer}

In 1847, the aged Dr Routh, president of Magdalen and one of the foremost scholars of his day, was asked what precept he could offer to guide and sustain a young man embarking on a life of learning. After long thought, his face brightened and he spoke thus: "I think, sir, since you care for the advice of an old man sir, you will find it a very good practice always to verify your references, sir." A pragmatic suggestion for our time might be "read Molecular Biology of the Cell, but don't drop it on your foot". This is very much the level of inspiration afforded by most scientific memoirs, often sponsored by charitable foundations, that have appeared in such numbers in recent years.

A collection of Sydney Brenner's writings arouses altogether higher expectations and I am happy to report that indeed it will disappoint no one, for here we have the authentic voice of the master himself. These pieces have appeared in the back of the monthly issues of Current Biology, which tend therefore to vanish from our library the day they arrive. The appearance of a new number is generally heralded for me by a call from a friend in a lab up the road, asking me whether I have yet read Brenner this month and regaling me with a few of the more outrageous squibs.

Loose Ends are reflections on biology and the scientific life. Uncle Syd's epistles to his nephew Willie treading the path of academic virtue from graduate student to institute director are laced with pungent anecdotes from an eventful life. Uncle Syd expatiates on the value of intellectual innocence and the treacherous nature of experimental phenomena; he informs Willy that the most abject of research students has the advantage of his professor, who has little time for such trivia as the work of his laboratory. "I have to warn you," he concludes, "that, sadly, this may be the only time in your career when you can enjoy research as an individual scientist."

As Willie comes to man's estate, Uncle Syd proffers solutions to the problems that now face him - how, for instance, to avoid committees and conferences: the only acceptable excuse, he asserts, is to plead a prior meeting. To add conviction, Uncle Syd once invented a highly exclusive and mysterious society, which spawned numerous subcommittees to keep its members perpetually occupied. But at a pinch, he suggests, an inscrutable reply to an unwanted invitation, on the lines of "I regret that I am unable to accept your invitation as I find I cannot attend your meeting", will often serve, and has even been known to elicit a courteous acknowledgement. This is undoubtedly better than the telegraphic formula that Proust was said to have employed when he was being lionized by Parisian society: "Regret unable to come. Lie follows."

Willies the world over may also profit from Uncle Syd's tips on how to manipulate the old enemy, the bureaucrat. You can avert unpleasing decisions in committee by waiting until the administrators have formulated replies to your arguments and then confess that you were wrong after all and return to the original point. "You can do this," the wily Uncle Syd explains, "because the hallmark of a scientist is to be able to change one's views depending on the evidence; no administrator can do this." Here he is undoubtedly right. The legendary academic casuist Maurice Bowra gave it as principle never to allow scientists on committees: they were unreliable, he found, because their opinions could be changed by arguments. (It was also Bowra who announced, when outvoted by five to one, that the committee had evidently reached an impasse.)

Uncle Syd has also worked out how to use the telephone as a weapon, merely by reversing the postures of the caller and the respondent. This is an excellent device: when you have got past three secretaries and the Olympian grandee at the head of the organization finally comes on the line, you greet him with: "Why, hello, Sir Marmaduke, and what can I do for you today?"

In dilating on the seven deadly sins and their consequences, Uncle Syd again points a moral or two with some tantalizing anecdotes. Who was that editor of "an important biological journal" who submitted his work in an unworthy $\mathrm{PhD}$ thesis, examined and frivolously approved by Uncle Syd? The topic gives a clue, but a tormenting doubt hangs in the air. I believe, incidentally, that the seventh sin is not sloth, as here, but rather accidie, which lies somewhere between boredom and indifference. To me this is encapsulated by the perhaps rather sensible principle that if a research project is not worth doing at all it is not worth doing properly.

"Molecular Biology by Numbers" finds Brenner in top form with reflections on the science that he and a few friends mostly created. The number 1 stands for the principle of one gene, one enzyme, 2 the diploid chro- 